\title{
The Masonry Block Industry in Akwa Ibom State: Challenges and Prospects of Entrepreneurial Development
}

\author{
Emmanuel Tayo $\mathrm{Adu}^{1 *} \quad$ M.A.O. Oladele ${ }^{2} \quad$ A. T. Lashinde ${ }^{1}$ \\ 1.Department of Quantity Surveying, University of Uyo, Uyo, Akwa Ibom State, Nigeria \\ 2. Department of Architecture, University of Uyo, Uyo, Akwa Ibom State, Nigeria
}

\begin{abstract}
The study investigates the challenges and prospects of entrepreneurial development of Small and Medium scale Enterprises (SMEs). The focus is on the masonry block industry in Akwa Ibom State. Data used for the analyses were collected through 139 returned and valid structured questionnaires, administered on the respondents including, owners/managers of masonry block industry, small and medium size contractors. Data collected was analysed using percentage, mean item score and Kruskal Wallis Rank test. The results reveal a high level of patronage and prospect for entrepreneurship growth of SMEs masonry block industry. The further reveal ready availability of products, time/energy savings, material efficiency, quality control, and employment opportunities among the major prospective advantages of SMEs masonry block industry. Major challenges confronting entrepreneurial growth and development of SMEs masonry block industry in the study area include inadequate funding, high cost of production, inflation, unstable patronage, and poor managerial skill. The study recommends that government should provide an enabling business environment and infrastructures through its Support Initiatives and Policies for masonry block industry to thrive in addition to the provision of business enabling infrastructure in ensuring increased productivity, reduction in production cost and profit optimization.
\end{abstract}

Keywords: Economic Growth, Employment, Developing Nation, Entrepreneurship, SMEs.

DOI: $10.7176 / C E R / 11-10-04$

Publication date: November $30^{\text {th }} 2019$

\section{Introduction}

National growth and development depends largely on the viability of entrepreneurial activities as well as contributions from both federal and state government. Developed and developing economies alike are fast driven by activities of SMEs at all levels. According to Ogbo \& Agu (2012) small and medium size enterprises (SMEs) play a very significant role in national development. Similarly, Metu \& Nwokoye (2014) view SMEs as one of the major contributors of economic and social development in any country. Ayodeji (2015) observes that entrepreneurial development and operations across the globe are viable mechanisms and means of efficient economic progression. Anyadike et al. (2012) opine that entrepreneurship when and if gallantly developed in Nigeria will take its pride of place in quelling unemployment and thus generating employment among Nigerian youths especially young graduates and place the economy on a proper footing. The impacts of entrepreneurship on the economy of any nation cannot be over emphasized. Muritala et al. (2012) summarize the impact of entrepreneurship which includes greater utilisation of local raw materials, employment generation, encouragement of rural development, development of entrepreneurship, mobilisation of local savings, linkages with bigger industries, provision of regional balance by spreading investments more evenly, creation of avenues for selfemployment and opportunity for training managers and semi-skilled workers.

There is a strong link between entrepreneurship and the construction industry; and from a global perspective, it is fundamental to the growth and development of the industry. The construction industry is a multi-disciplinary endeavour which involves different trades, professionals, skilled and unskilled personnel interacting together to provide necessary input at different phases from inception to completion of the project (Akinsiku \& Olubunmi 2014). These unique features provide a lot of prospects and opportunities for entrepreneurial growth in the industry. Research findings by Lowe (2003) shows that the industry offers value which ranges from $7 \%$ to $10 \%$ for a highly developed economy and around 3\% to $6 \%$ for undeveloped economies. Its high potential of generating employment opportunities at non-skilled and skilled levels and contribution to the nation through its cost-saving value approach of scarce resources are part of the significant attributes of the industry compared to other industries. However, focus on some of the entrepreneurial opportunities that could have generated massive employment for the teeming population has not been given adequate attention. In Nigeria for instance, the monolithic nature of its economy, that is, its heavy dependence on crude oil for more than $90 \%$ of her foreign exchange earnings (Metu \& Nwokoye 2014) has redirected the focus with little or no emphases on other sectors of the economy. This lack of attitude at investing in other sectors especially construction and agriculture remains one of the major causes of the perennial problems of unemployment, poor standard of living among others currently being witnessed in the country.

Government so far have made huge efforts to promote entrepreneurship and SMEs through Support Initiatives which can be traced back to 1964 (Oghojafor et al. (2011). Some of the initiatives include World Bank SME I 
AND II Loan Schemes, NERFUND (National Economy Reconstruction Fund), National Poverty Eradication, Advisory Agencies, Bank of Industry, Micro Finance Banks, SMIEIS (Small and Medium Industries Equity Investment Scheme), and The Nigerian Agricultural and Rural Development Bank Credit Scheme and the Seed Capital for Small Business. Despite all these numerous programmes and schemes that have been designed by different governments at different times, entrepreneurial development in Nigeria is very slow (Diyoke 2014). Studies show that these efforts failed to produce the desired results mainly because of poor implementation (Okezie et al. 2013; Adejumo \& Olaoye 2012). Consequent on the failure of these Initiatives and Support programmes, the country is still classified as one of the poorest countries in the world and is rated as a low economic development nation with low standard of living, high rate of unemployment, increase in poverty; as well as evident socioeconomic and political inadequacies (Ayodeji 2015). Reports also reveal about $70 \%$ (that is, 105 million) of Nigerians live below the poverty line against 54\% reported in 2008 (National Bureau of Statistics 2010).

Previous researches have attempted to identify the prospects and challenges of SMEs in developing nations (Agboli \& Ukaegbu 2006; Adejumo \& Olaoye 2012; Afolabi 2013). Anyadike et al. (2012) undertook a study on entrepreneurial development and employment generation in Nigeria focusing on the problems and prospects. Okezie et al. (2013) similarly carried out a review on challenges and prospects of entrepreneurship in Nigeria without specific mention of any particular sector or industry. In the same vein, Ayodeji (2015) in study on entrepreneurial development and barriers in a developing nation uses a case study of the Nigerian printing SMEs. Afolabi et al. (2016) also carried out a review on entrepreneurial opportunities in the production of building materials which include cement production, paint production, tile production and steel reinforcement production. The prospects identified include consistent increase in the demand for products and services, social purposes, domestic purposes, source of innovation, employment opportunities among others. Factors such as unfavourable business environment, cumbersome bureaucracy, high lending rates, lack of viable entrepreneurial skills, inadequate financial infrastructure, changing government policy, keen competition for limited opportunities and corruption, were identified as major challenges facing small and medium scale enterprises. Inferences from the foregoing show that there is no previous research that singled out SMEs masonry block industry for investigation in order to identify its prospects and challenge. This may be as a result of the fact that contribution of this sector has been grossly ignored. The sector of the economy is capable of producing massive employment, boost socioeconomic activities, and curb youth unrest in the nation. Research shows that this category of SMEs, particularly in Nigeria dies within the first five years of existence (Aremu \& Adeyemi 2011). In order to close the gap in literature, this study intends to provide an insight into SMEs masonry block industry with the aim to enhance its sustainability and relevance to the construction market. Specifically the objectives of the study are to ascertain the level of prospect and the specific challenges of entrepreneurial development of SMEs masonry block industry in Akwa Ibom State. Results of the findings of this study will be useful in raising the awareness and knowledge of stakeholders in the industry of the challenges facing the growth and development of SMEs masonry block industry with the view to revive and ensure its contribution to the economy and the nation at large. It will also add to existing literature on entrepreneurship and enhances growth of SMEs masonry block industry and other allied industries in the study area and the nation at large as well as proposing solutions to the perennial problems associated with the operation of the industry.

\section{Entrepreneurship defined}

There is no agreed universal definition of entrepreneurship as there are many schools of thought and diverse applications. It is a multifaceted phenomenon that cuts across many disciplines including industries and social services. However, some scholars have attempted to define entrepreneurship based on their diverse knowledge and backgrounds. Eckhardt \& Shane (2003) view entrepreneurship as a business process which encompasses identification and appraisal of opportunities, the choice to exploit or sell them, efforts to acquire resources, the development of appropriate strategy, and the design of the new project. Duru (2011) describes entrepreneurship from the perspective of functions of an entrepreneur, which include an inventor, imitator, innovator, or more appropriately as a calculated risk taker. Diyoke (2014) defines entrepreneurship as the dynamic process of creating incremental wealth. According to Diyoke (2014), wealth is created by individuals who assume the major risks in terms of equity, time and career commitment or provide value for some products or unique services, but value must somehow be infused by the entrepreneur by receiving and locating the necessary skills and resources. Ayodeji (2015) emphasized the importance of concentrating on personal view of entrepreneurship since entrepreneurs successfully identify an opportunity, initiate ideas to utilize, take an action to implement the idea and at end, establish a new business or product or service. Entrepreneurship therefore generally provides a platform for identifying gap in economic terms with the intention to fill it with innovative ideas capable of meeting the needs of individual and the nation for the desire goods and services in return for satisfaction, self-fulfilment and profit. As a result, entrepreneurship plays critical roles in national development by promoting economic development, employment opportunities, improvement in the standard of living through innovation, reduction in rural-urban drifts, development of local technological base, and conservation of foreign exchanges (Okezie et al. 2013; 
Adejumo 2000).

\subsection{Who is an Entrepreneur?}

Generally, "entrepreneur" can best be defined with respect to its cardinal functions and expectations. The entrepreneur dreams, invents, creates and figures out how to convert an idea or dream into a profitable reality, always searches for change, responds to and exploits change as an opportunity (Drucker 1985; Diyoke 2014). The entrepreneur is also viewed as originator or creator of a profit-seeking or economic organization, and as an individual who takes risks (Hisrich et al. 2005; Ogundele \& Abiola 2012). This shows the relevance of an entrepreneur in actualizing the desired needs that promote the wellbeing of the citizenry and the nation at large. This also indicates that entrepreneurs are significant in any nation as a result of the roles they play in modifying rural and urban areas through income generation and employment generation (Hallberg 2000; Williams 2001). Being an entrepreneur is self motivating. Some of the motivating factors of becoming an entrepreneur in any sector including the construction industry are, namely: feeling of personal satisfaction, source of innovative idea and business opportunity backed up with the ability to start business, prevailing problems in current jobs or lack of job, and realizing the need of earning money (Segal et al. 2005; Ogbo \& Agu 2012)

\subsection{Challenges of Entrepreneurial Development}

There are different challenges militating against the growth and development of entrepreneurship both in the developed and developing countries. These challenges or barriers are described as any condition, problematic circumstance from within or outside, making it quite difficult to make progress or achieve an objective following the system and environment of practice (Onugu 2005; OECD 2008). Couples of scholars from different sectors and countries have carried out studies on challenges in the context of entrepreneurship. Onuoha (1994) points out that inadequate capital, incompetent management, lack of technological and infrastructural facilities are the common problems facing entrepreneurship. Salami (2011) carried out a study on entrepreneurship interventionism and challenges of youth unemployment in Nigeria. The three major factors identified by the author that hinder entrepreneurship are: structural, cultural and the lack of political will by policy makers. Agbeze (2012) in another study identified non-accessibility to local and international markets, absence of a viable credit policy that address the specific needs of the enterprises, difficulty in procuring business approval, multiplicity of taxation, high inflation and other macroeconomic distortions among the several challenges facing aspiring entrepreneurs. Okezie et al. (2013) identified several variables that constitute the challenges of entrepreneurial development in Nigeria. These are: lack of credit facilities, corruption, inconsistent government policies, multiple taxation, and poor state of the country's infrastructure. Diyoke (2014) in a related study on entrepreneurship development in Nigeria concludes that sourcing of capital, expertise in management of the business, poor investment decisions are the major challenges of entrepreneurship development in Nigeria. The impact of these challenges on entrepreneurship is devastating especially in developing countries like Nigeria. The state of infrastructure affects entrepreneurs and in most cases discourages young and intending entrepreneurs. Poor state of the infrastructure which can be classified into economic infrastructure (transport, communications, power generation, water supply and sanitation facilities) and social infrastructure (educational and health-care facilities) has been observed as having serious negative impact on entrepreneurial growth which is the current state of Nigeria today (Akinbami et al. 2012). In addition, epileptic power supply has caused majority of factories in Nigeria to resort to the use of generators which add to production cost and further reduction in profit margin. Similarly, inconsistency in government policy and regulation poses a major challenge for the growth of entrepreneurship. Chittithaworn et al. (2011) observe that inadequate government efforts and insincere incentives for entrepreneurial development appear to have retarded the process of entrepreneurship development in many developing countries. Most efforts made by government are often not backed up by effective implementation or perhaps are defective in their formulation and conceptualization. Communication system was an endangering situation to the growth and development of entrepreneurship in the past, but both the previous and current government has made grand slide achievements in this area by investing huge capital on telecommunication. However, there is still room for improvement and consolidation of the present achievement. In order to provide a unifying basis for the factors identified by the various authors, the study has collated the factors and sources from extant literature and classified them as challenges of entrepreneurial growth and development as shown in Table 1. 
Table 1: Challenges of Entrepreneurial Growth and Development

\begin{tabular}{|c|l|l|}
\hline S/N & Factors & Sources \\
\hline 1 & Inadequate capital & $\begin{array}{l}\text { Diyoke 2014; Adejumo \& Olaoye 2012; Chowdhury 2007; } \\
\text { Agbeze 2012; Ogundele \& Abiola 2006. }\end{array}$ \\
\hline 2 & Corruption & $\begin{array}{l}\text { Adejumo \& Olaoye 2012; Okezie } \text { et al. 2013; Diyoke } \\
2014 .\end{array}$ \\
\hline 3 & Inconsistent Government Policies & $\begin{array}{l}\text { Okezie } \text { et al. 2013; Ndubuisi 2004; Adejumo \& Olaoye } \\
2012 .\end{array}$ \\
\hline 4 & Multiple taxation & Agbeze 2012. \\
\hline 5 & Poor road infrastructure/maintenance & Okezie et al. 2013. \\
\hline 6 & $\begin{array}{l}\text { Failure to adapt to the changing business } \\
\text { environment }\end{array}$ & Okezie et al. 2013. \\
\hline 7 & Low standard of education & Okezie et al. 2013. \\
\hline 8 & Security issues & $\begin{array}{l}\text { Metu \& Nwokoye 2014; Agbeze 2012; Okezie } \text { et al. 2013; } \\
\text { Diyoke 2014. }\end{array}$ \\
\hline 9 & Poor planning & Okezie et al. 2013. \\
\hline 10 & Poor product or service & Okezie et al. 2013. \\
\hline 11 & Political and social movements & Okezie et al. 2013. \\
\hline 12 & economic problem & Kivrak \& Arslan 2008; Okezie et al. 2013. \\
\hline 13 & $\begin{array}{l}\text { Lack of competent and skilled } \\
\text { management }\end{array}$ & Diyoke 2014. \\
\hline 14 & Epileptic power supply & Metu \& Nwokoye 2014; Diyoke 2014. \\
\hline 15 & Unwillingness to take risk & Ikupolati et al. 2017. \\
\hline 16 & Poor leadership and coordination & $\begin{array}{l}\text { Agbeze 2012; Adejumo \& Olaoye 2012; Diyoke 2014; } \\
\text { Chan \& Tam 2000. }\end{array}$ \\
\hline 17 & Poor managerial capacity & Onuoha 1994; Obele-Agu 2000; Olawale \& Garwe 2010. \\
\hline 18 & Low technological capacities & Onuoha 1994; Ndubuisi 2004. \\
\hline 19 & High cost of production. & Metu \& Nwokoye 2014; Ndubuisi 2004. \\
\hline 20 & Location issues & Bruyant \& Julien 2001. \\
\hline 21 & Legal and regulatory constraints & Ogundele \& Abiola 2006. \\
\hline 22 & Lack of requisite knowledge & Adejumo \& Olaoye 2012. \\
\hline & & \\
\hline
\end{tabular}

\section{Masonry Block Industry in Akwa Ibom State}

Entrepreneurship offers great opportunities for SMEs to thrive in the construction industry. The SMEs are recognized as having the required potential of ensuring a self-reliant industrialization, in terms of ability to rely largely on local raw materials, generate and boost employment, guarantee a more even distribution of industrial development in the country, including rural areas. The nature of construction business has led to the evolvement of many trades in meeting the needs of the industry. These include metal work, glazing, painting, carpentry, concrete work and block work. These trades offer a lot of opportunities for job creation and reviving socioeconomic activities in any nation. Government intervention in this area in expanding and promoting its products and services in this country is scored very low. However, the scope of the current study is limited to masonry cement/block SMEs in Akwa Ibom State.

Production of masonry brick/block is often carried out by SMEs in most cases outside the construction site. Masonry block is one of the strongest and most valuable building materials used in all forms of construction such as residential, commercial, and industrial buildings. The products come in different varieties, namely: four inch block, six inch block and nine inch block. The market for the production and distribution of commercial masonry brick/block for building projects emerged as a small scale enterprise. The aim of the entrepreneurs in this subsector is to ensure ready availability of the products for customers as and at when due and to maximize profit from the investment. The increasing need to build new residential houses, factories and offices to accommodate Nigerian's large population has made cement block production a very lucrative business in the country (Business Plan Nigeria, 2018). Poor site management practices and confined nature of sites especially in built-up areas in the cities also tend to favour the growth of the market for masonry brick/block. Contractors can take advantage of masonry block industry on projects that demand early delivery for time conscious clients in the construction industry.

Masonry block industry is however capital and labour intensive. It is a risky venture due to associated losses, stealing, breakages and accident in the course of production and delivery of the products. Just like every other SMEs, there are attributes that entrepreneurs of masonry block industry need to possess for effective and efficient 
daily operation. A typical cement block entrepreneur must have good networking relationship with individuals and corporate customers. In addition he must possess the necessary skills, good level of patience and time for the job, ensure effective delivery of goods to customers at desired locations. It is important to note that good quality, durability, reliability, packaging and prompt delivery of the products are basic ingredients to ensure fair competition among other producers. The sector plays a crucial role in regulating the quality of products that go into construction. The contribution of block moulding industry to the economy of a nation is imperative as a result of largeness of the market, its nature and potentials in creating jobs and employment. It has been noted that this category of enterprise is an engine through which the growth objectives of developing countries can be achieved and a potential source of income in many developing countries (Kayanula \& Quartey 2000). Despite the high importance and contributions of this sub-sector of the industry to the growth and development of the nation, it has suffered a huge setback due to diverse problems which this study intends to address.

\section{Research Methodology}

This study was carried out within the three geo-political zone of Akwa Ibom State. The state is one of the prominent states in the South-South zone, Niger-Delta of Nigeria. The choice of the location was based on the expansion and increase in the socio-economic activities in the area which has resulted in the demand for more private and public buildings to cater for the growing population. The study employed survey research design approach which involved the use of structured questionnaire in order to achieve the objectives of the study. The survey research method was deemed appropriate since the study sought to investigate the prospects and challenges of entrepreneurial development of SMEs masonry block industry. The study population consists of masonry block industry and the construction industry in Akwa Ibom State. The target population was directors/owners of masonry block industry, small and medium size (SME) contractors in the built environment. SME contractors among all the professionals in the construction industry were only in the study apart from SMEs masonry block owners/managers because it was discovered the literatures that these two categories of contractors were mostly involved in the execution public building projects in the study area. Hence, a major patronage of masonry blocks industry. The sampling frame of 286 involved in the study was collated in two parts. The first part is the list of owners/directors of masonry block industry collated during pilot survey that was early conducted before administering questionnaire. The second part is from the list of contractors that registered with corporate organizations, state and federal establishments in the State. Consequently, the quota and random sampling techniques were adopted for the study. The quota sampling technique was used because of unpredictable numbers of registered SMEs masonry block owners/managers operating in selected areas for the survey. Therefore, the sample size obtained for the finite population was 167 using Taro Yamane formula for finite populations (Olusanya 2018).

The questionnaire used in the study consists of 3 sections. Section A elicits information on the respondents` backgrounds. Section B solicits information on the prospective factors of prospects of masonry block SMEs. The respondents were asked to rank the relative importance of the factors using a five point Likert-scale ranged from 1 to 5 adapted from Nkado \& Mbachu (2002) where, 1 represents 'No importance', 2 'low importance', 3 'moderate importance', 4 'high importance', and 5 'very high importance'. Section C consists of 22 variables of challenges of entrepreneurship identified from literature which also affect the growth and development of masonry block SMEs. The respondents were also requested to rank the relative effect of the factors based on a five point Likert-scale where, 1 represents 'No effect', 2 'low effect', 3 'moderate effect', 4 `high effect', and 5 'very high effect'. A total of 139 questionnaires duly completed and returned and valid were used for the analyses. The views of the respondents were compared may be or not they differ in their perception on the factors constituting the prospects of masonry block enterprises and relative effect of the challenges on entrepreneurial growth and development of masonry block enterprise in the study area. This led to the postulation of two hypotheses:

$\mathrm{Ho}_{1}$ : $\quad$ There is no significant variation in the factors constituting the prospects of

masonry block industry among the perceptions of the respondents; and

$\mathrm{Ho}_{2}$ : There is no significant variation in the relative effect of the challenges of masonry

block industry among the perceptions of the various respondents.

Data collected were processed using Microsoft Excel and Statistical Package for Social Science (SPSS). The ranking of the factors was determined based on the Mean Score (MS) which was calculated by the following equation:

$\mathrm{MS}=\Sigma\left(\mathrm{R}_{\mathrm{Pi}} \mathrm{R}_{\mathrm{i}}\right) / \mathrm{n},(1 \leq 11 \leq 5) \ldots \ldots \ldots \ldots .$. Equation $(1)$

Where MS = Mean Score, $\mathrm{R}_{\mathrm{Pi}_{i}}=$ Rating Point I (range from 1 - 5)

$R_{i}=$ Response to rating point, $i$ and $n=$ total responses $=$ Summation of $R_{i}$ from 1 to 5 .

The analysis was done to determine the level of importance and effect of the factors on entrepreneurial growth of masonry block SMEs. MS was derived as the total score divided by the number of respondents for each factor. A 
baseline of MS $=3.5$, was used to determine the significance of the factors. Factors having an MS $\geq 3.5$ were considered as significant while factors with an $\mathrm{MS}<3.5$ as insignificant based on previous studies conducted by Kazaz et al. (2008). The two hypotheses of the study were analysed using Kruskal Wallis tests.

\section{Results and Discussions}

This section presents the results and discussion arising from the analyses of the data collected for the study. This includes the test of the two hypotheses of the study; the prospective factors of prospects of SMEs masonry block industry and relative effects of the challenges of masonry block industry.

5.1 Level of patronage and prospect of entrepreneurial development of masonry block SMEs

The perceptions of the respondents were sought in order to investigate the level of patronage and prospects of entrepreneurial development of masonry block SMEs using a five-point scale ranging for 5 to 1 where 5 represents very high and 1not at all as previously stated. The data collected was analysed and presented in Table 3 and Table 4 as shown below.

Table 3: Level of patronage of masonry block SMEs

\begin{tabular}{lcc}
\hline Level of patronage & Frequency & Percent (\%) \\
\hline Very High & 56 & $40.51 \%$ \\
High & 41 & $29.25 \%$ \\
Moderate & 30 & $21.48 \%$ \\
Fair & 12 & $8.76 \%$ \\
Not all & 0 & $0.00 \%$ \\
\hline
\end{tabular}

Table 4: Level of prospects of entrepreneurial development of masonry block SMEs

\begin{tabular}{lcc}
\hline Level of prospect & Frequency & Percent (\%) \\
\hline Very High & 51 & $36.52 \%$ \\
High & 44 & $31.75 \%$ \\
Moderate & 34 & $24.31 \%$ \\
Fair & 10 & $7.42 \%$ \\
Not all & 0 & $0.00 \%$ \\
\hline
\end{tabular}

Table 3 shows that majority (40.51\%) of the respondents perceive that the level of patronage of masonry block SMEs by the end users in the area as very high. The least response of the patronage of the industry which is fair is at $8.76 \%$. This implies the approval of the products of the industry in terms of quality and other beneficiary services offers by the industry to the general public especially the construction industry. Result of the analysis in Table 4 shows that majority $(36.52 \%)$ of the respondents indicate that the level of prospect of entrepreneurial development of masonry block SMEs in the area as very high while the least of the prospects of the industry which is fair is at $7.42 \%$. This indicates that if government invests more in this sector of the economy, more people will be gainfully employed and therefore reduce the level of employment especially among the youth. If some of the construction materials are produced locally it will definitely help to cut down on imported goods and at the same time reduce the cost of building. This is in agreement with Akinmoladun \& Oluwoye (2007) who earlier emphasized on the imperativeness of enhancing entrepreneurial opportunities in the local production of building materials with the view to reduce the prices of imported building materials and components in addition to having a sustainable construction environment. Nigeria is a developing nation abundantly endowed with natural resources; entrepreneurs should exploit these opportunities for the socio-economy development of the country. Unemployed youth and graduates should avail themselves of this opportunity to earn a living.

\subsection{Analysis of the Prospective Factors of Prospects of Masonry Block SMEs}

The section below present the result of analysis of the prospective factors of the prospect of masonry block SMEs based on the data collected from the respondents. The presentation was in two stages: test for comparison among the three respondent groups on the induced factors of prospects of masonry block SMEs and the ranking of the relative importance of the induced factors of prospects of masonry block SMEs.

5.2.1 Test for Comparison of the Relative Importance of the Prospective Factors of Prospects of Masonry Block SMEs

Research makes it clear that masonry block SMEs among other sectors in the construction industry offer numerous benefits to different sizes of contractors especially small and medium in the built environment. The benefits are defined in this study as the induced factors of the prospects of masonry block enterprises. The first hypothesis of this study which was earlier stated was therefore postulated to ascertain whether or not each of the three categories of the respondents have the same perception about the selected prospective factors of the prospects of masonry block enterprises in the study area. The hypothesis was tested using Kruskal-Wallis Test at $p \leq 0.05$. The rule for the rejection or non-rejection of the hypothesis is that if $\mathrm{p}$-value $>0.05$, the test fails to reject the hypothesis but if 
$\mathrm{p}$-value $\leq 0.05$, the test rejects the hypothesis. The result is as presented in Table 5 .

Table 5: Result of Kruskal Wallis Test

\begin{tabular}{lllllll}
\hline & Group & N & $\begin{array}{c}\text { Mean } \\
\text { Rank }\end{array}$ & $\left(\boldsymbol{x}^{2}\right)$ & P-value & Decision \\
\hline Respondents & Masonry block entrepreneurs & 12 & 17.88 & 0.289 & 0.866 & Accept \\
& Small size Contractors & 12 & 17.79 & & & \\
& Medium Contractors & 12 & 19.83 & & & \\
& Total & 36 & & & & \\
\hline
\end{tabular}

The result of the Kruskal Wallis test presented in Table 5 shows that the calculated chi-square $\left(\varkappa^{2}\right)$ value of 0.289 was less than the table value of 3.841. This implies that there is no significant difference in the perceptions of owners of masonry block enterprise, small size contractors and medium size contractors on the prospective factors of the prospect of masonry block enterprises in the study area. The p-value (assymp. sig.) of 0.866 which is greater than 0.05 further confirms that there is no significant difference in the perceptions of the respondents on the prospective factors of the prospects of masonry block enterprise. This also shows that the respondents are well aware of the factors capable of promoting entrepreneurial growth and development of masonry block enterprises in the study area.

5.2.2 Ranking of the Prospective Factors of Prospect of Masonry generated Block Industry Enterprise

The agreement among owners of masonry block enterprises, small size contractors and medium size contractors on the prospective factors of prospect of masonry block enterprises in the study area indicates that further analysis on the data from the respondent groups can be combined for further analysis since they do not significantly differ. The data were analysed to determine the relative importance of each of the factors based on the perception of the respondents. The result of the analysis is shown in Table 6.

Table 6: Prospective Factors of Prospect of masonry block SMEs

\begin{tabular}{lccc}
\hline Factors & Mean & Rank & Remarks \\
\hline Ready availability of product & 4.76 & $1^{\text {st }}$ & VHS \\
Time/energy savings & 4.69 & $2^{\text {nd }}$ & VHS \\
Material efficiency & 4.00 & $3^{\text {rd }}$ & VHS \\
Quality control & 4.52 & $4^{\text {th }}$ & VHS \\
Employment opportunities & 4.48 & $5^{\text {th }}$ & VHS \\
Economic development & 4.41 & 6 & HS \\
Site management & 4.24 & 7 & HS \\
Reduction in rural-urban drifts & 3.91 & 8 & HS \\
Cost effectiveness & 3.84 & 9 & HS \\
Source of innovation and material research & 3.76 & 10 & HS \\
Development of local technological base & 3.71 & 11 & HS \\
Cost optimization & 3.59 & 12 & HS
\end{tabular}

The result in Table 6 shows that all the factors considered in this study have MS greater than the hypothesized MS of 3.5. This indicates that the respondents sampled believe that all of the factors are significant with the MS ranging from 4.76 to 3.59 . Based on the results of the study, the prospective factors of the prospects of masonry block SMEs in the study area is very significant. This also implies that the masonry block enterprises are not only beneficial to the construction industry and individuals but also to the nation at large. Out of the twelve induced factors of the prospect of masonry block SMEs considered in the study, the first five highly ranked of the factors and their respective MSs include: ready availability of product (MS=4.76), time/energy savings $(\mathrm{MS}=4.69)$, material efficiency $(\mathrm{MS}=4.60)$, quality control $(\mathrm{MS}=4.52)$, and employment opportunities $(\mathrm{MS}=4.48)$. The least three factors are source of innovation (MS=3.76), development of local technological base (MS=3.71), and cost optimization ( $\mathrm{MS}=3.59)$ while the remaining factors are in between.

Ready availability of products from masonry block industry is very crucial in meeting the modern-day procurement systems where early completion time is highly demanded. Availability of products in the right quantities in the construction market saves a lot of time and energy that could have been expended in the fabrication of the products on site within the agreed limited contract period. Consequently, speedy construction on site which ensures early completion and hand-over can be easily achieved. In addition, cases of poor performance of construction projects such as time delays caused by resource shortage, poor site management, and inadequate planning can be minimized through the availability of the use of prefabricated masonry blocks. Quality control of the products is one of the critical factors that induced the prospects of masonry block enterprises. This is essentially important in the current spate of building collapse which is mostly attributed to poor workmanship and deficiency in the quality of materials. Construction quality encompasses quality of materials used in construction works (Rumane 2011) which is one of the attributes of masonry block products. This in essence fosters the prospect of the industry among other similar endeavours. Quality control of masonry blocks among other things exhibits some inherent advantages which include durability and robustness of the products provided all the normal standards and 
regulations are adhered to. This results to a long lasting and stable structure which can be simple to maintain. Other benefits that the prefabricated masonry block produced in factory conditions has over conventional construction method, that is, site-based construction includes opportunity to be properly cured and be closely monitored by plant employees, weather independence as well as working capabilities (Sivapriya \& Senthamilkumar 2016), Though cost of transport, erection and attendant overheads of operating a production facility add to the total cost of the product but these can be traded off by the potential savings offered by mass production, economies of scale and scope (Sivapriya \& Senthamilkumar 2016)

5.3 Analysis of the relative effects of challenges of masonry block enterprise on its growth and development Operations of masonry block enterprise are not without its challenges from internal to external factors. These factors affect not only the growth but also the development of the enterprise at varying degrees. This section presents the results of the analyses of the effects of challenges of masonry block enterprise on its growth and development. The result of the test for comparison of the effects of the identified challenges of the entrepreneurial growth of masonry block enterprise based on the data collected from the three groups of respondents was first presented followed by the result of the ranking of the variable factors as presented in the sections below.

5.3.1 Test for comparison of the relative effects of the challenges of masonry block industry on its growth and development

The second hypothesis of the study which has already been stated was to determine whether or not the three categories of respondents have the same perception concerning the relative effect of the variable factors constituting challenges as identified in this study on entrepreneurial growth and development of SMEs masonry block industry in the study area. This test of agreement among other things became necessary in order to provide a basis for further research and recommendation based on the data collected as to whether the effect of the challenges on the development of this sub-sector of construction industry can be generalized among the three groups of respondents. In order to test whether or not the three categories of respondents have same perception concerning the relative effect of the factors on the development of masonry block industry, a Kruskal-Wallis test was performed. The rule for the rejection or non-rejection of the hypothesis is that if $p$-value $>0.05$, the test fails to reject the hypothesis but if $p$-value $\leq 0.05$, the test rejects the hypothesis. The results are presented in Table 7 . Table 7: Result of Kruskal Wallis Test

\begin{tabular}{lllllll}
\hline & Group & N & $\begin{array}{c}\text { Mean } \\
\text { Rank }\end{array}$ & $\left(\boldsymbol{x}^{\mathbf{2}}\right)$ & P-value & Decision \\
\hline Respondents & Masonry block industry & 22 & 32.70 & 0.06 & 0.971 & Accept \\
& Small size contractor & 22 & 33.75 & & & \\
& Medium size contractor & 22 & 34.05 & & & \\
& Total & 66 & & & & \\
\hline
\end{tabular}

Table 7 shows the result of the Kruskal Wallis test with the calculated chi-square $\left(x^{2}\right)$ value of 0.06 was less than the table value of 3.841. This implies that there is no significant difference in the perception of owners of masonry block industry, small size contractors as well as medium size contractors of the relative effect of challenges on entrepreneurial growth and development of masonry block enterprise in the study area. Further analysis indicates that the p-value (assymp. sig.) of 0.971 which is greater than 0.05 also confirms that there is no significant difference in the perception of respondents of the relative effect of the challenges on the entrepreneurial growth and development of masonry block enterprise. The agreement in the perception of the respondents could have been associated with both local and national factors which influence the respondents almost in the same manner. This agreement also implies that their combined perception and recommendation towards overcoming the challenges in the study area can be upheld.

5.3.2 Ranking of the selected challenges on the growth and development of masonry block enterprise

Further analysis was carried out based on the combined data generated from the three respondent groups to determine the significance of the variable factors contributing to the challenges of masonry block industry. This consists of twenty two variable groups of that data collected using questionnaire administered on the respondents. The result of the analysis which indicate the MS and rank of each of the factors is as presented in Table 8. 
Table 8: Challenges affecting the growth and development masonry block enterprise

\begin{tabular}{|c|c|c|c|}
\hline Factors & Mean & Rank & Remarks \\
\hline Inadequate funding /lack of credit) & 4.76 & $1^{\text {st }}$ & VHS \\
\hline High cost of production. & 4.64 & $2^{\text {nd }}$ & VHS \\
\hline Inflation & 4.53 & $3^{\text {rd }}$ & VHS \\
\hline Unstable patronage & 4.48 & 4th & VHS \\
\hline Poor managerial skill & 4.43 & $5^{\text {th }}$ & VHS \\
\hline Price fluctuation & 4.38 & $6^{\text {th }}$ & HS \\
\hline Poor state of Infrastructure & 4.33 & $7^{\text {th }}$ & HS \\
\hline Location (proximity) & 4.29 & $8^{\text {th }}$ & HS \\
\hline Failure to adapt to the Changing Business Environment & 4.26 & $9^{\text {th }}$ & HS \\
\hline Technological deficiency & 4.21 & $10^{\text {th }}$ & HS \\
\hline Lack of competent and skilled personnel & 4.16 & $11^{\text {th }}$ & HS \\
\hline Low Standard of Education & 4.14 & $12^{\text {th }}$ & HS \\
\hline Poor craftsmanship & 4.10 & $13^{\text {th }}$ & HS \\
\hline Political and social movements & 4.09 & $14^{\text {th }}$ & HS \\
\hline Inconsistent Government policies & 3.38 & $15^{\text {th }}$ & MS \\
\hline Security Issues & 3.29 & $16^{\text {th }}$ & MS \\
\hline Material mismanagement & 3.22 & $17^{\text {th }}$ & MS \\
\hline Unfavourable weather conditions & 3.05 & $18^{\text {th }}$ & MS \\
\hline Unhealthy completion & 1.95 & $19^{\text {th }}$ & LS \\
\hline Pilfering & 1.79 & $20^{\text {th }}$ & NS \\
\hline Violent clashes of militant groups & 1.24 & $21^{\text {st }}$ & NS \\
\hline Multiple Taxation & 1.17 & $22^{\text {nd }}$ & NS \\
\hline
\end{tabular}

The result in Table 8 shows that out of twenty two variable factors of challenges affecting the growth and development of the masonry block SMEs considered in this study, fourteen have MS greater than or equal to the hypothesized MS of 3.5 in the range of 4.76 to 4.09. This means that the other eight have MS less than 3.5 in a range of 3.38 to 1.17 . This result implies that these fourteen factors have significant effect while the other eight factors have no significant effect. The most highly ranked of all is inadequate funding with $\mathrm{MS}=4.76$ while the least is multiple taxation with $\mathrm{MS}=1.17$. Other factors such as high cost of production, inflation, unstable patronage and poor managerial skill were among the first five major challenges of masonry block SMEs in the study area.

The findings of the study are in agreement with Bacdom (2004), Iromaka (2006), Aremu (2010) who attribute lack of credit facilities as one of the major constraints to the realization of the full benefits of SMEs. Availability and accessibility of credit facility is a major issue in Nigeria being a developing nation though equally endowed with many natural resources. Most aspiring entrepreneurs are of low income earners and cannot access credit facilities due to high interest rates charged by banks and other lending institutions. In addition, other issues such as insufficient collateral, is part of conditions that must be fulfilled before they can access fund (Afolabi 2013). Other difficulties face by SMEs in accessing bank finance may be due to evidence of substantial risks of loss even though there may be possibilities of high returns on the investment; policy regulation as well as cost of capital (Kayanula \& Quartey 2000; Gounden 2000). High cost of production is directly influenced by high cost of energy especially from petroleum products. For instance, increase in energy Premium Motor Spirit (PMS) price will negatively impact on the production of the firms or individuals (household) (Orlu 2017). Production or cost of masonry block increases with the increase in high energy costs (Windapo \& Cattell 2012). This confirms the findings by Humphrey \& Nana (2018) that crude oil price is the most significant variable responsible for increasing prices of building materials in the Ghanaian Construction Market. A large portion of the energy utilized for the manufacturing of building materials is subject to the use of crude oil, once the expenses of crude oil heightens, the cost required in producing energy will likewise increase; consequently the production cost also increase (Bencivenga et al. 2010).

The situation of high energy cost is also exacerbated by poor state of road infrastructure which affects not only entrepreneurs but also the nation at large. This is consistent with Akinbami et al. (2012) who affirm that entrepreneurial growth in Nigeria has been negatively affected by poor and inadequate infrastructural facilities such as roads, electricity and supply of pipe-borne water. Studies show that inflation affects the cost of materials and overall cost of construction (Nnadi 2015). The effect of inflation on masonry block SMEs and the economy is very worrisome. Inflation occurs when the prices of goods and services increase over time (Kimani \& Mutuku 2013). Due to ripple effect on other macro-economic factors the economy is affected much more (Lynn 2007). The SMEs masonry block industries are seriously affected, because one of the major components of the product which is cement is directly influenced by the trend of inflation. Period of high inflation affects sales because of reduction in demand for housing which ultimately affect the return on investment. Unstable patronage caused by low demand for masonry blocks cuts down on production, increase establishment charges, and even temporary 
closure of the factory due to liquidation. Owner's experience count at this period in order to keep of the business afloat. According to Thwala \& Mvubu (2008) experience in any kind of management is very important and plays a crucial role in ensuring that a business succeeds or fails. Poor managerial skill as revealed in this study is one of the major challenges facing SMEs especially in the developing nations. Good management implies awareness of all factors making up a successful business namely; good strategy, marketing, pricing and financial controls. Highly important among these attributes is managerial competence which is a set of knowledge, skills, behaviour and attitudes that contribute to personal effectiveness (Hellriegel et al. 2008). Other factors that were considered insignificant based on the results of the analysis include multiple taxation, violent clashes of militant groups, and pilfering. Though these factors were considered insignificant, however, the dynamic chain reaction in construction business due to certain factors such as environment, political settings can trigger these factors and consequently become critical and highly significant. The professionals in the built environment should be concerned about this and therefore accord the factors of great importance.

\section{Conclusion and recommendations}

The study investigates the challenges and prospects of entrepreneurial growth and development of the masonry block SMEs in Akwa Ibom State. A questionnaire was designed and distributed among the three major groups of participants - owners/managers of masonry block industry, small size contractors and medium size contractors for data collection. The study concludes that there is high level patronage of masonry block SMEs which consequently enhances its entrepreneurial prospects in the study area. The study also concludes a strong agreement in the perception of owners of masonry block SMEs, small size contractors and medium size contractors on the prospective factors of the prospects of SMEs masonry block industry in the study area. It is also concluded that SMEs masonry block industry offers a lot of prospect out of which ready availability of products, time/energy savings, and material efficiency, quality control, and employment opportunities top the list of the prospect. The study further concludes that there is agreement in the perception of respondents on the relative effect of challenges of masonry block SMEs in study area out of which inadequate funding, high cost of production, inflation, unstable patronage, poor managerial skill, price fluctuation, and poor state of infrastructure are dominant challenges confronting entrepreneurial growth and development of SMEs masonry block industry in the study area. The study recommends that government should provide an enabling environment through its Support Initiatives and Policies for SMEs masonry block industry to thrive in addition to provision of business enabling infrastructure in order to increase productivity, reduce production costs and profit optimization. Emphasis should be placed on the teaching of entrepreneurship not only in tertiary institutions but also in the secondary schools. Lastly, the entrepreneurs and workers of masonry block industry should acquire basic skills and seek for new methods and techniques for competitive advantage.

\section{References}

Adejumo, D.G., \& Olaoye. J.A. (2012), "Roles and problems of small-scale business development programmes in Nigeria", International Journal of Management \& Business Studies 2(1).

Afolabi, M.O. (2013), "Growth effect of small and medium enterprises (SMEs) financing in Nigeria", Journal of African Macroeconomic Review 3(1).

Afolabi, A., Oyeyipo, O., Ojelabi., R., \& Emeghe, I. (2016), "Entrepreneurial opportunities in the production of building materials", Journal of Economics and Sustainable Development 7(4), 15-25.

Agbeze, C. (2012), "Entrepreneurship: The need to create wealth-why not now", Ohafia today 2(32), 7-12.

Agboli, M., \& Ukaegbu, C. (2006), "Business environment and entrepreneurial activity in Nigeria: implications for industrial development", The Journal of Modern African Studies 44(1), 1-30.

Akinbami, C.A.O., Aluko, M.A.O., \& Momodu, A.S. (2012), "Technology adoption and women entrepreneurial behaviour: Case of agro-allied businesses in rural South Western Nigerian communities", International Journal of Science and Technology 1(10), 509-523.

Akinmoladun, O.I., \& Oluwoye, J.O. (2007), "An assessment of why the problems of housing shortages persist in developing countries: A case study of Lagos Metropolis, Nigeria", Pakistan Journal of Social Sciences 4(4), $589-598$

Akinsiku, O.E., \& Olubunmi, A.J. (2014), “Correlates of clients' payment patterns and construction project performance" In: Laryea, S. and Ibem, E. (Eds) Proceedings 8th Construction Industry Development Board (cidb) Postgraduate Conference, 10-11 February 2014, University of the Witwatersrand, Johannesburg, South Africa, 223-232.

Anyadike, N., Emeh, I.E.J., \& Ukah, F.O. (2012), "Entrepreneurship development and employment generation in Nigeria: Problems and prospects". Universal Journal of Education and General Studies 1(4), 88-102.

Aremu, M. A., \& Adeyemi, S.L. (2011), "Small and medium scale enterprises as a survival for employment generation in Nigeria”, Journal of Sustainable Development 4(1), 200-206. 
Aremu, M.A. (2010), "Small and Medium Scale Enterprises as a Means of Employment Generation ND Capacity Building in Nigeria", A paper Presented at the International Conference on Management and Enterprise Development on, "Intellectual and New Strategies for Sustainability Development of the Third World" Held at Conference Center, University of Ibadan, Ibadan, Nigeria, October 5 - 8, 39-48.

Ayodeji, M.A. (2015), "Entrepreneurial development barriers in a developing nation: A case study", Master's Thesis. An MSc Thesis submitted to the Department of Masters of Business Administration, Hamk University of Applied Science.

Bacdon, C.T. (2004), "Small scale industries and economic development in Ghana: Business and Strategies in informal sector Economics", VerlagBreitenbech, Saarbruckh, Germany, 19-23.

Bencivenga, C., Sargenti, G., \& D’Ecclesia, R. (2010), "Energy Markets: Crucial Relationship between Prices", In: Corazza, M. and Pizzi, C., Eds., Mathematical and Statistical Methods for Actuarial Sciences and Finance, Springer, Berlin, 23-32. $\quad$ https://doi.org/10.1007/978-88-470-1481-7_3

Bruyant, C., \& Julien, P.A. (2001), "Defining the field of research in entrepreneurship", Journal of Business Venturing 16, 165-180.

Business Plan Nigeria (2018). https://www.businessplannigeria.com.ng/concrete-block-moulding-plan/ Last accessed: May, 2018.

Chittithaworn, C., Islam, M.A., Keawchana, T., \& Yusuf, D.H.M. (2011), "Factors affecting business success of small and medium enterprises (SMEs) in Thailand", Asian Social Science, 7(5), 182-190. ttps://doi.org/10.5539/ass.v7n5p180

Chowdhury, M.S. (2007), “Overcoming entrepreneurial development constraints: A case of Bangladesh", Journal of Enterprising Communities: People and Places in the Global Economy 1(3), 240 - 251.

Diyoke, C.I. (2014), "Entrepreneurship development in Nigeria: Issues, problems and prospects", International Journal of Technical Research and Applications 10, 19-23.

Duru, M. (2011), "Entrepreneurship opportunities and challenges in Nigeria", Business and Management Review 1(1), 41-48.

Drucker, P.F. (1985), “Innovation and Entrepreneurship”, London: Pan Books Ltd.

Gounden, S. (2000), "The impact of the National Department of Public Works' Affirmative procurement policy on the participation and growth of affirmable business enterprises in the construction sector", Unpublished $\mathrm{PhD}$ thesis, University of Natal, Durban.

Hallberg, K. (2000), “A market-oriented strategy for small and medium-scale enterprises IFC” Discussion Paper Number 40. Washington, D.C.: International Finance Corporation.

Hellriegel, D., Jackson, S.E., \& Slocum, J.W. (2008), “Managing: A competency based approach” (11th ed.). Mason, $\mathrm{OH}$ : Thomson South-Western.

Hisrich, D.R., Shepherd, A.D., \& Peters, P.M. (2005), "Entrepreneurship”, 6th Ed: New York, McGraw-Hill/Irwin

Danso, H., \& Nana, K.O. (2018), "Major determinants of prices increase of building materials on Ghanaian construction market” Open Journal of Civil Engineering 8, 142-154 http://www.scirp.org/journal/ojce

Iromaka, C. (2006), “Entrepreneurship in small business firms”, Ikeja: G-Mag. Investments Ltd, (Educational Publishers), 49-56.

Kayanula, D., \& Quartey, P. (2000), “The Policy Environment for Promoting Small and Medium-Sized Enterprises in Ghana and Malawi”, Finance and Development Research Programme, Working Paper Series, Paper No 15, IDPM, University of Manchester.

Kazaz, A., Manisali, E., \& Ulubeyli, S. (2008), "Effect of basic motivational factors on construction workforce productivity in Turkey", Journal of Civil Engineering and Management 14(2), 95-106.

Kimani, D.K., \& Mutuku, C.M. (2013), "Inflation Dynamics on the Overall Stock Market Performance: The case of Nairobi Securities Exchange in Kenya", Economics and Finance Review 2(11), 1-11.

Lewis, J.L., \& Sheppard, S.R.J. (2006), “Culture and communication: Can landscape visualization improve forest management consultation with indigenous communities?" Landscape and Urban Planning 77, 291-313.

Lim, C., \& Mohamed, M. (2000), “An exploratory study into recurring construction problems", International Journal of Project Management 18, 267-273.

Lowe, J.L. (2003), "Construction Economics”, www.callnetuk.come/home/johnlowe. Access: June, 2016

Lynn (2007), "The tectonic forces of global real estate: Implication for global investment and Portfolio Managers", Journal of Real estate portfolio Management 13(1), 87-92.

Memon, A.H., Rahman, I.A., Abdullah, M.R., \& Azis, A.A.A. (2010), "Factors affecting construction cost in Mara large construction project: Perspective of project management consultant", International Journal of Sustainability in Construction Engineering Technology 1(2).

Metu, A.G., \& Nwokoye, E.S. (2014), "Entrepreneurship development in Nigeria: Prospects and challenges", International Conference on Entrepreneurship: Strategy for Socio-Economic advancement in Emerging Economies, organized by the Department of Business Administration, Faculty of Social and Management Sciences, Bowen University Iwo, 28-30th May 2014. 
Muritala, T.A., Awolaja, A.M., \& Yusuf, B. (2012), "Impact of small and medium enterprises on economic growth and development", American Journal of Business and 1(1), 18-22.

National Bureau of Statistics. (2010), "Statistical News: Labor Force Statistics", No. 476. Abuja: The NBS

Nkado, R., \& Mbachu, J. (2002), "Causes of, and solutions to client dissatisfaction in the South African building industry: The clients perspectives", Proceedings of CIB W107 1st International Conference: Creating a Sustainable Construction Industry in Developing Countries, 11-13 October, Stellenbosch, South Africa, pp. 349-357.

Nnadi, E.O E. (2015), “An evaluation of cost of construction projects on Nigerian economy", In: Proceedings of the Nigerian Institute of Quantity Surveyors: $2^{\text {nd }}$ Research Conference - NIQS ReCon2, 1-3 September, Akure, 692-705.

Obele-Agu, N.C. (2003), “Contemporary Business management”, Enugu Optional (Books) Publisher.

Ogbo, A., \& Agu, A.C. (2012), "The role of entrepreneurship in economic development: The Nigerian perspective", European Journal of Business and Management. 4(8).

Oghojafor, B.E.A., Okonji, P.S., Olayemi, O.O., \& Okolie, J.U. (2011), "Fifty years of entrepreneurship development in Nigeria: Challenges and prospects", 10th International Entrepreneurship Forum, Tamkeen, Bahrain, 9-11 January.

Ogundele, O.J.K., \& Abiola, J.O. (2006), “Entrepreneurship and national development: A proposal for evangelistic agenda", European Scientific Journal 8(6), 40-70.

Okezie, A.I., .Alex, O. \& Asoluka, C.N. (2013), "Challenges and prospects of entrepreneurship in Nigeria", Academic Journal of Interdisciplinary Studies 2(5), 25-36.

Olusanya, O.A. (2018), "Subcontracting systems and social protection in the informal building construction industry in Lagos, Nigeria", Journal of Construction Business and Management 2(1). 10-19.

Onugu, B.A.N. (2005), "Small and medium enterprises (SMEs) in Nigeria: Problems and Prospects", PhD Dissertation, St. Clements University

Onuoha, B.C. (1994), "Entrepreneurial Development in Nigeria”, Okigwe, Alvan Global Publications.

Orlu, R.N. (2017), "The impact of domestic pricing of petrol on economic growth of Nigeria (1970 - 2013)", Global Journal of Social Sciences 16, 1-8.

Rumane, R. (2011), “Quality management in construction projects”, Crc Press, 8-20.

Salami, C.G.E. (2011), "Entrepreneurship interventionism and challenges of youth unemployment in Nigeria", Global journal of management and business research 2(7).

Salter, A., \& Torbett, R. (2003), "Innovation and performance in engineering design", Journal of Construction Management and Economics 21, 573-580.

Segal, G., Borgia, D., \& Schoenfeld, J. (2005), “The motivation to become an entrepreneur”, International Journal of Entrepreneurial Behaviour and Research 11(1), 42-57.

Sivapriya, C., \& Senthamilkumar, S. (2016), "Building cost comparison of precast concrete construction with conventional construction", International Journal of Innovative Research in Science, Engineering and Technology 5(5), 8037-8044.

Thwala, W.D., \& Mvubu, (2008), "Current challenges and problems facing small and medium size contractors in Swaziland", African Journal of Business Management 2(5), 093-098.

Timmons, J. (1999), “New Venture Creation: Entrepreneurship for the 21st Century”, Boston: Irwin/McGrawHill.

Williams, T. (2001), “Accessing extension of time delays on major project”, International Journal of Project Management 21(4), 19-26.

Windapo, A., \& Cattell, K. (2012), "Examining the trends in building material prices: Built environment stakeholders' perspectives", Management of Construction. 1, 187-201. https://www.irbnet.de/daten/iconda/CIB_DC25658.pdf 